\title{
개발 협력 변수로서 \\ 국제 안보 정세 변화에 대한 이해
}

\section{목차}

I. 서론

II. 국제 안보 정세 변화에서 주목할 8개 지역

1. 둘로 나뉜 이슬람 세계

2. 아프가니스탄: 지정학적 이해 충돌지역

3. 캐쉬미르: 인더스 강 활용에 따른 물 전쟁 가능 지역

4. 아프리카: 천연 자원 확보에 따른 이해상충 지역

5. 발칸 반도: 역사적 갈등이 잠재된 지역

6. 코카서스: 에너지 안보의 이해관계 충돌지역

7. 한반도: 신 양극체제의 최전방

8. 북극: 새로운 자원 개발에 따른 이해 상충 지역

III. 결론

\section{I. 서론}

세계의 특정 지역이나 국가와 경제 및 정치적 교류와 협력에 앞서 우선적으로 파악해야 하는 중요한 사항 중에 하나가 해당 지역 또는 국가의 안보 정세이다. 이 같은 맥락에서 개발 협력 사 안을 진행함에 있어서도 국제 안보 정세 변화의 추이에 대해서 인지할 필요가 있다. 그 주된 이 유는 적합한 개발 협력 전략을 수립할 수 있을 뿐만 아니라 개발 협력의 효과를 예측하는데 도움 이 되기 때문이다.

국제 안보 정세란 다자간의 외교와 국방관련 사안들을 총체적으로 보여주는 것이어서 복잡성 
의 문제가 뒤따른다. 이 복잡성은 큰 틀을 갖고 설명될 때 좀 더 명확하게 파악된다. 필자는 국제 안보 정세 변화의 틀을 2008년 출간된 〈세계 부와 경제를 지배하는 3 개의 축〉을 통해서 미국과 유럽을 합친 서구 세계를 1축으로, 이슬람 세계를 2축으로, 그리고 나머지 국가군을 3 축으로 분 류해서 설명한 적이 있다. '3개의 축(The Three Axes)'으로 분류한 근거는 2001년 9/11 이후 세계 안보 문제가 문명의 충돌 양상을 보이고 있기에 1 축과 2 축의 대립을 부각시켜 설명을 시도 했다.

그런데 2008년 금융 위기 이후의 세계 안보 정세의 새로운 추이를 필자는 2009년 5월 미래 전략연구원의 “21세기 나토의 위상과 역할”이라는 기고를 통해서 신 양극체제의 등장을 피력한 바 있다. 이 같은 주장을 토대로 2010년 출간된 〈우리만 모르는 5년후 한국 경제〉에서 과거 냉 전 시절 미국과 소련의 대립, 즉 자유민주 진영과 공산 진영이라는 이데올로기적 이분법으로 설 명되던 것과 차별화 되는 신 양극 체제는 미국이 주도하는 북대서양조양기구(NATO)와 그 친 나 토 국가군을 PATO (Pro-American Treaty Organization)라 칭하고, 중국과 러시아가 주도하 고 있는 상해협력기구(Sanghai Cooperation Organization)을 중심으로 한 친 SCO 국가군으로 분류하며 신 양극체제의 등장을 다음과 같이 기술하고 있다:

바르샤바조약기구가 소멸되었을 때, 많은 사람들은 나토(North Atlantic Treaty Organization)의 존재자체가 무의미해졌다고 생각했었다. 비록 소련과 바르샤바동맹국에 의한 군사적 위협은 없어 졌지만 유럽주둔 미군은 감축된 상태로 그대로 잔류하고 있다. 동시에 나토는 작전 반경을 유럽 밖으로 뻗치면서 친 서방 또는 친미의 범세계적 집단안보체제인 '파토(PATO: Pro-American Treaty Organization)'로의 확대일로에 있다. 이런 맥락에서 미국은 유럽 밖의 친미 국가인 일본, 호주, 한국을 나토와 협력관계를 통하여 범세계적 집단안보체제의 구축을 도모하고 있다. 파토 (PATO)의 경쟁국가들은 상해협력기구(SCO)회원국들과 이란, 시리아 같은 아랍의 반 서방 국가 들, 그리고 베네수엘라, 콜롬비아, 페루, 브라질 같은 남미의 반미 성향의 국가들과 아프리카에서 중국의 영향권 하에 있는 수단, 앙골라, 잠비아, 남아공 등이 $\mathrm{PATO}$ 권과 대립양상을 보이고 있 다. 이와 같은 대립 현상은 21세기 국제질서의 새로운 패러다임인 '신 양극 체제(New Bi-Polar System)'라 부른다. 


\section{III. 국제 안보 정세 변화에서 주목할 8 개 지역}

이런 맥락에서 이번 기고 글은 신 양극 체제의 틀에서 국제 안보 정세의 변화 추이를 8개 지역 으로 나누어 다룬다.

제 I 장

제 II 장

\section{1. 둘로 나뉜 이슬람 세계}

이슬람 세계는 전 세계 56 개국으로 총 인구는 약 16 억에 이른다. 종교적으로 같은 가치를 나 누는 이 거대한 축이 오스만 투르크 시절처럼 결집력을 발휘한다면 국제적 위상이 지금보다 휠씬 더 높아 질 것이다. 하지만 이슬람 세계의 현실은 국제역학구도에 각각 다르게 대응하는 각국의 지도자들에 의해서 사분오열된 상태다.

이슬람 세계가 본격적으로 국제무대에 등장한 시기는 많은 아랍국가들이 영국과 프랑스의 통치 하에 있다가 2 차 대전이 끝나고 독립을 맞은 시점부터이다. 이슬람 세계의 대표적인 통합 노력은 1945년의 아랍 연맹(Arab League) 창설, 1981년의 걸프협력이사회(Gulf Cooperation Council) 창설, 그리고 1989년의 아랍 마그레브 연맹(Arab Maghreb Union)창설이다. 이 중에 걸프협력 이사회(GCC)를 빼고는 별다른 성과를 거두지 못했다.

석유가 주요 에너지 자원으로 이용되면서 원유를 부존자원으로 가진 아랍국가들은 경제적 이득을 통해 국가 발전의 토대를 마련하게 되었다. 그러나 문제는 석유를 통한 경제적 이득에 따라 오히려 이슬람 세계가 가진 나라와 못 가진 나라로 나뉘고, 또 친 서방국가와 반 서방국가로 나뉘게 만드는 부정적 요소로 작용하고 있다. 뿐만 아니라 1948년 다시 건국된 이스라엘이 오히려 아랍세계의 단 합이 아닌 분열요소로 작용하고 있다 (조명진, 2008). 이와 같은 상황을 잘 파악하고 있는 러시아 와 중국은 반 서방 국가들인 시어파인 시리아와 이란 같은 중동 국가와 관계를 돈독히 해왔다.

\section{가. 아랍 통합의 한계}

22 개 회원국을 가진 아랍 연맹의 창설 목적은 중동의 평화와 안전을 확보하고 아랍제국의 주 권과 독립을 수호하기 위한 지역협력기구를 만드는 것이다. 그 일환으로 1950 년 4월 13 일 '공동 방위 및 경제협력에 관한 조약'이 조인되면서 군사적 방어조치에 대한 조정권도 갖게 되었다. 그 러나 1956년 2차 중동전쟁에서, 1967년 3차 중동전쟁, 그리고 1973년 4차 중동전에서 이스라엘 을 공동의 적으로 간주하는 아랍연맹의 연합군은 형성되지 않았다. 무엇보다도 이스라엘이 네 차 례에 걸친 인근 아랍국가와의 전쟁에서 승리한 요인은 영국, 프랑스, 미국 같은 서방세계가 이스 
라엘을 지원해 주었다는 것이다.

아랍 연맹이 경제 협력 같은 비정치 분야에서는 상당한 성과를 거두었다고 평가하지만, 연맹내 의 정치적 문제에서는 사우디아라비아 등 보수적인 왕국들간의 이권다툼과 내재된 갈등으로 진전 을 보이지 못하고 있다. 특히, 이스라엘과 팔레스타인에 관한 문제에서 조차 아랍 연맹은 한 목소 리를 내지 못하고 있다. 더욱이 ISIL의 등장으로 아랍 연맹의 주축 국가인 이집트와 사우디 아라 비아가 반 서구적 태도를 보이면서 아랍세계의 분열의 골은 점점 깊어지는 양상이고, 국내적으로 도 반 정부 및 반 왕실 세력들을 키워 내정에 불안요소가 가중되고 있다.

\section{나. 통합의 진전- 걸프 협력 이사회(Gulf Cooperation Council)}

걸프 협력 이사회(GCC)는 이란 이라크 전쟁 발발의 영향으로 1981년 아라비아 반도에 위치한 6 개국 (사우디아라비아, 바레인, 쿠웨이트, 오만, 카타르, 아랍 에미레이트)에 의해 창립되었다. 예멘은 2016년 가입 예정이다. 창립 목적은 회원국에 대한 안보문제를 공동으로 대처하자는 것이 다. 아랍 연맹과 아랍 마그레브 연맹과는 달리, $\mathrm{GCC}$ 는 6 개 회원국 간의 농업, 산업, 투자, 안보, 무역 등의 광범위한 분야에서 협력을 통해 실질적인 성과를 보여왔다. 그 예로 1982 년 걸프 표준 화 기구(Gulf Standards Organization)와 1984년 걸프 투자 회사 설립을 들 수 있다.

총 3천 3백만 인구의 GCC는 7000억 달러의 국내 총생산(GDP)의 경제규모를 지닌 친서방 아 랍국가군이다. $\mathrm{GCC}$ 중 바레인과 오만을 제외한 4개국이 $\mathrm{OPEC}$ 회원국인데, GCC 국가들은 세계 석유매장량의 $45 \%$ 를 보유하고, 세계 원유 공급의 $20 \%$ 를 차지하여 지난 30 년간 원유 수출로 급 속한 경제발전을 이루었다. 또한 GCC의 경제는 사우디아라비아, 아랍에미레이트, 카타르 3개국 의 외자유치와 해외투자를 통해 주도되고 있다. 아랍에미레이트의 투자 기관인 아부다비 펀드 (Abu Dhabi Fund)의 자산은 1조 달러에 이른다.

GCC는 단일 통화인 칼레지(Khaleeji)을 2010년까지 도입하는 것을 목표로 했으나 아랍에미레 이트의 거부로 본래의 취지인 통합 진척의 결실을 보지 못하고 있다. GCC는 경제 분야 뿐만 아 니라, 국방측면에서도 진척이 있었다. 회원국의 국방부 장관과 합참의장의 모임을 통해서 1982년 2개 여단규모의 '반도 방패군(Peninsula Shield Force)'을 창설했다.

1983 년과 1987 년 사이에 GCC은 6개 회원국 육군과 공군이 참가한 합동군사훈련 기회를 여러 차례 가졌다. 사우디아라비아와 쿠웨이트는 바레인의 공군력 증강을 위한 최신 전투기 구입과 호 르무즈 해협의 방어능력 향상을 위해서 오만에 군사원조를 제공하기도 했다. 하지만 1991년 걸프 전 때 쿠웨이트의 방어를 지원한다는 합의를 이집트와 시리아와 함께 이루었지만 실제로 군사적 조치는 없었다. 더구나 2003년의 이라크 전쟁에도 GCC가 군사적으로 개입한 바 없다. 
대외관계에 있어서 유럽연합은 GCC의 가장 중요한 무역파트너이다. EU와 GCC 관계는 1989 년 상호 경제협력을 증진시킨다는 데 동의서를 교환했다. 이들의 관계가 특히 밀접하게 된 것은 이라크 전쟁에 대한 후속조치로 $\mathrm{EU}$ 는 지중해 지역 국가와 중동지역에 대한 전략적 파트너십 관 계를 원했기 때문이다. 2005년 EU와 GCC는 테러리즘에 대한 자금지원을 막는다는 데 합의하여 테러와의 전쟁에 공조하는 모습을 보였다. GCC국가 중 아랍에미레이트, 카타르, 바레인은 유럽 대형 은행과 거래를 통해 의존도가 늘어나면서 더욱 친 서구 성향을 보이고 있다.

이슬람 세계의 또 다른 분열은 시리아 내전으로 다시 가열되고 있다. 2011년 발발한 시리아 내전은 이슬람 세계를 시어파와 수니파 국가간의 분쟁으로 격화시켜놓고 있다. 시어파인 아사드 정권을 같은 시어파의 맹주인 이란이 지원하고 있고, 반군을 수니파의 맹주인 사우디 아라비아가 지원하고 있다. 시리아 내전뿐만 아니라 예멘 내전 또한 수니파 정부군은 사우디 아라비아가 지 원하고, 반군은 이란이 지원하고 있어 이슬람 세계에게 두 종파간 역사적 분열의 골을 깊게 하는

대리 전 양상을 보이고 있다.

6개 강대국(6 Powers: UN 상임이사국 5 개국에 독일을 포함시킨 형태)과 이란과 핵 문제 타 결은 중동의 안보 구도를 재편하는 계기가 되고 있다. 그간 친 서방이었던 사우디 아라비아가 서 방 세계와 이란의 외교 관계 호전에 불편한 심기를 드러내면서 반 서방 기류를 타고 있다는 점은 세계 안보 정보의 또 다른 큰 변화이다.

국제 안보 정세가 원유가에 어떻게 변수로 작용했는지 주요 연도별로 살펴본다.

〈그림 1〉 국제 관계와 원유가 등락

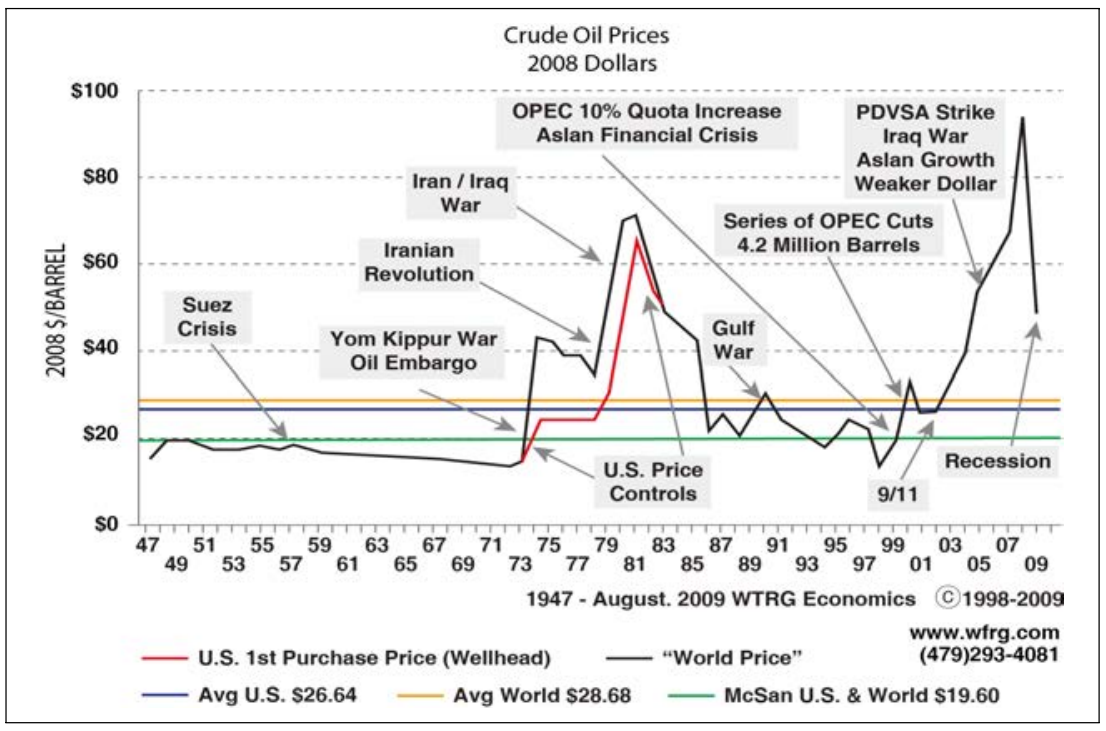

출처: http://kroncoholdings.com/wp-content/uploads/2010/07/G1.gif (접속일: 2016년3월) 
- 1973년 10월: OPEC 이 4차 중동전 (Yom Kippur War)에서 이스라엘을 지지하는 국가들 에 대한 원유수출 중단으로 1 년 안에 원유가격이 3 배나 뛰어 45 달러에 이르렀다.

- 1980년: 이란 인질사태로 원유가격이 80달러까지 치솟았다.

- 2001년 9월 11일: 9/11 사태로 미국 경기가 침체되면서 원유가격이 20달러로 하락했다.

- 2003년: 이라크 북부 송유관이 파괴되고 바그다드의 UN본부가 폭탄 테러를 당하면서 원유 가격은 30 달러로 올랐다.

- 2004년 5월: 원유 생산국가에 대한 테러위협과 러시아 유코스 사에 대한 푸틴의 영향력행사 로 인해서 원유가격이 40 달러로 인상되었다.

- 2005년 7월: 중국의 원유 소비량 증가와 이란의 핵 개발에 대한 우려로 원유가격이 60달러 까지 인상되었다.

- 2006년 4월: 미국의 원유 보유량 저하와 나이지리아의 소요, 그리고 이란 핵 프로그램에 대 한 국제 제재조치로 원유가격이 내리지 않고 70달러 선을 유지했다. ${ }^{1)}$

- 2007년 9월: 멕시코의 좌익세력이 6개 송유관을 공격함에 따라 원유가격이 80달러로 올랐다.

- 2008년 7월: 같은 해 1 월에 100 달러를 돌파한 유가는 6 월의 이스라엘의 대규모 군사 훈련 영향으로 가파른 상승세를 이어가다가, 7 월 이란의 미사일 시험발사로 사상 최고치인 147 달 러까지 급등했다. 하지만 2주 만에 125 달러 선으로 떨어졌다.

- 2008년 12월: 사상 최고치를 기록한 지 5개월 사이에 원유가격은 33 달러로 폭락했다.

\section{2. 아프가니스탄: 지정학적 이해 충돌지역}

아프가니스탄의 근대사는 세 번에 걸친 강대국의 침공으로 얼룩져 있다. 식민 제국주의 시대에 프랑스와 함께 세계 정복의 쌍두마차였던 영국이 1839년에서 1842년 사이에 아프가니스탄을 침략 했지만 정복에 실패하고 물러났다. 이어 냉전 시대인 1979년에서 1989년까지 소련군이 아프가니 스탄을 점령했다. $9 \cdot 11$ 사태 이후에는 아이러니하게도 미국을 위시한 북대서양조약기구 (NATO) 가 냉전 시대 미국 편이었던 탈레반을 상대로 ‘테러와의 전쟁’을 펼치고 있다.

2009년 창설 60 주년을 맞은 북대서양조약기구(NATO)는 냉전 중에 출범해서 냉전 후에도 존 속하고 있다. 냉전하의 나토 존재 명분은 바르샤바 조약기구와 대결구도였지만, 냉전 종식 후에는 9/11 사태에 따른 테러와의 전쟁이다. 하지만 집단안보체제인 나토에 위협이 되는 대상은 국가가 아닌 테러집단이고, 이러한 이유로 알 카에다의 본거지인 아프가니스탄에서 나토 작전의 성공 여 부는 나토 장래 위상에 중요한 변수이다.

1) http://www.cbc.ca/news/background/oil/forces.html (접속일: 2016년 3월) 
냉전 후 종전의 유럽 우방만이 아니라 냉전 시 적성 국가였던 바르샤바조약기구의 폴란드, 체 코, 헝가리가 1999 년 나토에 가입했다. 구소련의 위협이 잠정적인 점에서 바르샤바 조약기구 회 원국들의 나토 가입은 세계안보 구도를 바꾸는 역사적 사건이다. 게다가 미국에 대한 알 카에다 의 공격인 $9 / 11$ 사태는 나토에게 다시금 존재 명분을 주었다. 바로 '테러와의 전쟁'이다. 그리고 발트 3국(에스토니아, 라트비아, 리투아니아)과 루마니아, 불가리아가 2004년에 가입함으로써 나 토는 더 많은 옛 적성 국가들을 포용하며 확대되었다.

나토의 아프가니스탄 파병은 나토 헌장 5 조를 발동시켰기 때문이다. 나토 헌장 5 조는 "어느 한 회원국이 공격을 받으면 전체 회원국에 대한 도발로 간주해 모든 회원국이 공격 당한 회원국을 방어한다(an armed attack against one or more of them in Europe or North America shall be considered an attack against them all)"는 조항이다. 9/11 사태로 인한 테러와의 전쟁은 국가가 아닌 테러집단의 공격에 대해서도 나토 헌장 5 조를 확대 적용한 것이다.

미국의 입장에서 이라크 보다 아프가니스탄 우선정책을 펴는 배경은 다음과 같다. 우선 $9 / 11$ 의 주동자인 빈 라덴의 알 카에다 조직은 근거지를 아프가니스탄에 두고 있다. 빈 라덴이 건재한 상황에서 테러와의 전쟁은 명분이 있으며, 알 카에다가 미국과 '테러와의 전쟁'에 동조하는 국가들 에 위협요소가 되는 한 아프간 전쟁은 여론의 지지를 받을 수 있다. 더불어 성조기 아래 독자적 인 작전이 아닌 나토 깃발아래서 연합 작전을 펴기 때문에 리스크를 줄일 수 있다. 미군 전사자 숫자도 이라크의 4,416명(2010년 기준)에 비해 아프가니스탄에서는 1,249 명이어서 미국 내 여론 이 극으로 치닫지 않은 점 또한 요인으로 작용한다. 미국이 아프가니스탄에 전력을 집중하는 데 는 다음과 같이 세 가지 요인이 있다.

첫째, 미군 전력의 분배측면이다. 미군의 최대 전력 동원 능력은 동시에 두 전쟁을 치르는 것 이다. 아프가니스탄과 이라크에서 전쟁을 벌이고 있는 미국은 더 이상 또 다른 전쟁에 개입할 여 력이 없는 것이다. 이란과 북한과의 잠재적 무력 출동을 염두에 두자면 아프가니스탄과 이라크에 서 지속적인 전쟁을 펼 수가 없다.

둘째, 아프간 전쟁은 국제법상 적법한 무력 행위이다. 오바마 행정부가 '아프가니스탄 우선 정 책'을 천명하는 또 다른 이유는 다름 아닌 유엔의 승인을 받은 아프가니스탄에서의 작전은 국제법상 적법성을 띈다는 것이다. 다시 말해, 이라크 전쟁은 유엔 승인 없는 미국과 영국의 일방적 침공이 었으나, 아프가니스탄은 유엔에서 인정한 국제안보지원군((International Security Assistance Force, ISAF)의 작전 지역이다.

셋째, 아프가니스탄은 지정학적 중요성을 띤다. 아프가니스탄은 이란과 구소련 3개 공화국(투 르크메니스탄, 우즈베키스탄, 타지키스탄), 그리고 중국과 국경을 맞대고 있어서 나토의 주축으로 
서 미군의 주둔은 이들 국가에 대한 견제와 압력효과가 있기 때문이다(조명진, 2009a). ${ }^{2)}$ 나토군 의 아프가니스탄 주둔이 알 카에다의 제거만이 아닌 이란과 SCO회원국에 대한 견제 포석인 점에 서 장기화될 조짐이다. 왜냐하면 아프가니스탄에서 나토의 철군은 '힘의 공백(power vacuum)'으 로서 $\mathrm{SCO}$ 가 그 자리를 대신할 수 있기 때문이다.

러시아는 과거 소련의 아프가니스탄 정복 실패에 대한 콤플렉스를 지니고 있다. 아프가니스탄 에서 나토가 승승장구하는 것을 환영할 이유가 없다. 러시아는 상해 협력기구( $\mathrm{SCO}$ )를 통해 나토 에 대한 견제를 시작한 상황이다. 나토의 아프가니스탄 주둔은 중국 입장에서는 미국의 포위 정 책의 일환으로 해석할 수 있고, 러시아 입장에서는 러시아의 남진 차단용이라는 인식을 갖고 있 기 때문에 상해 협력기구(SCO)에서 양국이 협력적 전략 관계를 다지고 있는 것이다.

더욱이 알 카이다가 파키스탄 국경 지역으로 거점을 옮기고 있는 상황에서 아프가니스탄과 파 키스탄 정부의 도움을 받더라도 국경의 산악지대에서 알 카에다를 상대하기는 전술적으로 힘들다.

이라크의 유전 개발에 참여한 주요 업체가 $\mathrm{BP}$, 엑손 모빌, 쉘 등 서방 다국적 기업인 점을 감 안하면 아프가니스탄의 자원 개발도 나토에서 중추적인 역할을 하고 있는 미국을 위시한 나토 핵 심국이 될 것이라는 전망이다. 이라크에서 미군이 완전 철군하는 시점은 당초 2011년 말이었으 나, 아래 표에서 보여주듯이 2016년부터 1천 명의 미국 병력을 유지 시킬 계획을 갖고 있다는 점 은 신 양극 체제 틀에서 이해 가능한 부분이다.

〈그림 2〉미국과 나토 연합군 아프가니스탄 병력수 증감

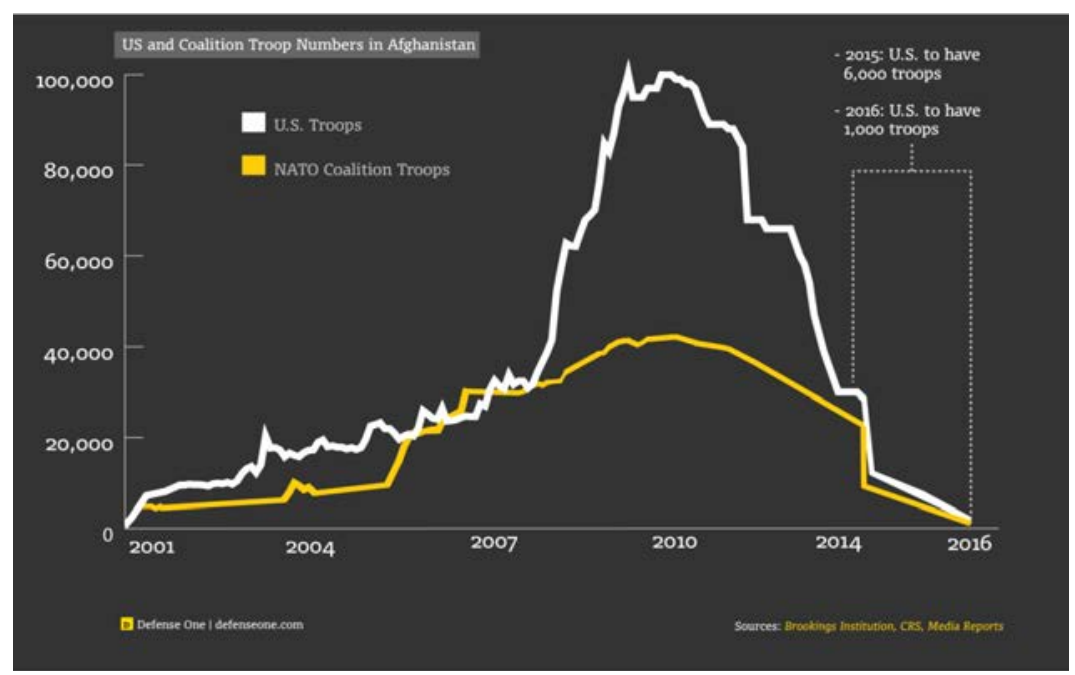

출처: http://www.brookings.edu/ /media/Programs/foreign-policy/afghanistan-index/index 20140110.pdf?la=en (접속일: 2016년 3월)

2) http://www.kifs.org/contents/sub3/trand.php?method=info\&searchKey=\&searchWord=\&offset=\&sld=2267\#content (접속일: 2016년 3월) 


\section{3. 캐쉬미르(Kashmir): 인더스 강 활용에 따른 물 전쟁 가능 지역}

인도와 파키스탄은 캐쉬미르 지역에서 1947년, 1985년, 그리고 1999년 3차례나 무력 충돌을 벌인 바 있다. 문제는 1984년 이후 시아첸 빙하(Siachen Glacier) 지역을 두고 양국간에 국지전 이 지속되고 있다는 사실이다. 캐쉬미르 지역에서 인도와 파키스탄을 나누는 국경선을 '제로 라인 (Zero Line)'이라고 부른다.

〈그림 3〉제로 라인

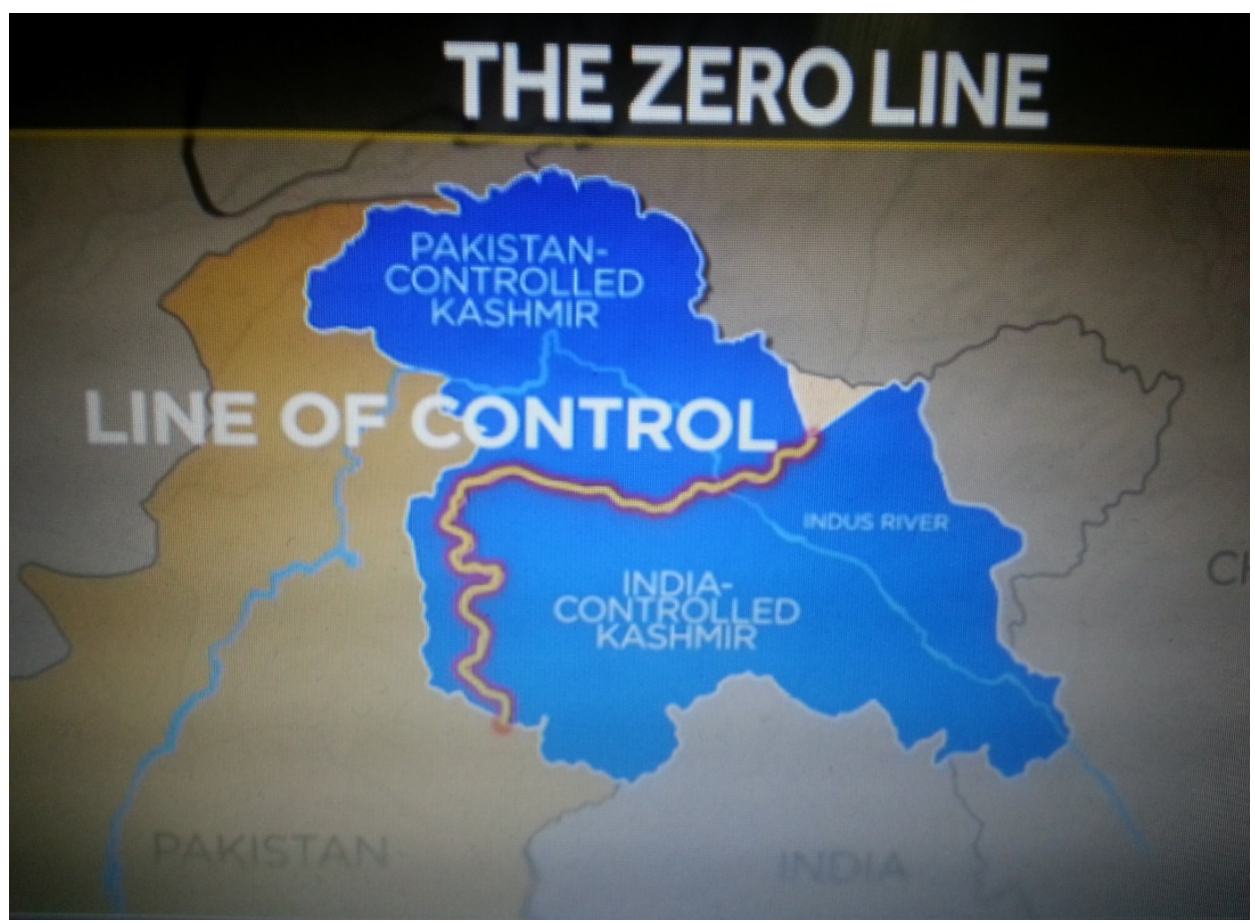

출처: http://moneymorning.com/zero-line-crisis-the-highest-battle-ground/ (접속일: 2016년 3월)

한반도를 나누는 휴전선의 비무장지대(DMZ)가 155 마일 $(250 \mathrm{~km})$ 인 반면, 제로 라인은 460 마 일 $(740 \mathrm{~km})$ 이나 걸쳐있고, 그 가운데 350 마일 $(500 \mathrm{~km}$ 넘게 $) 2.6 \mathrm{~m}$ 의 철조망이 놓여있다. 65 만 명 병력이 양측에 대치하고 있으며, 휴전 중이지만 간헐적인 교전으로 양측 그동안 6만 명 사상 자 발생했다. 한반도의 휴전선이 전 세계에서 '가장 요새화된 국경(the most fortified border)' 으로 알려졌다면, 제로 라인은 '가장 군사적으로 위험한 국경(the most dangerous militarized border)'로 불린다.

산업화와 인구 증가에 따른 물 수요 증가로 인해서 인더스 강에 대한 물 분쟁은 양국 에 잠복 
된 분쟁 변수이다. 캐쉬미르의 인도 진영에서 발원하는 인더스 강은 파키스탄 농업 용수의 $90 \%$ 공급원이고, 국가 고용의 $50 \%$ 그리고 국내총생산(GDP)의 $25 \%$ 를 차지하는 중요한 수자원이다. 1960 년 양국간의 협정은 인도는 수력발전과 농사개간용으로 인더스 강의 수자원을 활용할 권리 를 허용하고 있다.

문제는 그간의 급격한 인구 증가이다. 1960 년 파키스탄은 인구 4 천 5 백만이었는데 현재는 1 억 7 천만으로 늘어났고, 인도는 4 억 5 천만 명에서 12 억으로 증가해서 그만큼 수자원에 대한 수요가 증대한 상태이고, 양국의 출산율이 증가하는 것을 상정했을 때 인도의 수자원의 독점에 따른 물 부족 사태가 예견되고 있다.

인구 증가는 전기 사용량 또한 증가시키고 있다. 1960 년 이래로 전기 사용량이 파키스탄의 경 우 $613 \%$ 증가했고, 인도는 그간 전기료를 $500 \%$ 인상했다. 파키스탄의 수도 카라치는 인더스강 가장 하류에 위치하고 있고, 캐쉬미르 지역으로부터 842마일 떨어져 있다. 인도는 45개의 추가 수력발전소를 건설 계획하고 진행 중 결과적으로 강물 흐름을 막아서, 하류에 수량이 감소가 예 상된다. 양국의 인더스 강에 대한 물 전쟁은 핵전쟁으로 발전할 가능성이 있다는 점이다.

인도는 110 기와 파키스탄 120 기의 핵탄두를 보유하고 있어서 양국의 분쟁 시에 핵을 사용한 선제 공격 가능성은 해당 지역뿐만 아닌 세계 안보 정세에 최악의 시나리오가 된다. ${ }^{3)}$ 왜냐하면 인도가 보유하고 있는 아그니 5(Agni 5) 대륙간탄도미사일(ICBM)은 사정거리가 3500마일(5500 $\mathrm{km}$ )로 북경, 일본, 러시아는 물론 터키와 일부 유럽까지 사정권에 두고 있다. 만약 파키스탄 인 도간의 핵전쟁이 발발하면 미국증시 7 8조 달러 가치 폭락될 것으로 예측된다.

이와 함께 더욱 위험스러운 요소는 파키스탄 내 알카에다를 포함한 8개 극단 이슬람 조직 (Radical Islamic Fractions)이 근거지를 두고 있어서 이들에 의한 핵사용 가능성이다. 이들 테 러조직에는 M.A.D(Mutual Assured Destruction)4)이 적용되지 않는다는 점에서 우려하게 된다.

\section{4. 아프리카: 천연 자원 확보에 따른 이해상충 지역}

중국의 아프리카 교역은 2000년에서 2010년까지 10년간 10배가 증가하는 놀라운 상승세를 보였다.5) 문제는 아프리카 천연자원과 에너지 자원에 대한 중국의 공략이 미국의 이해관계와 충

3) 전세계에서 핵 보유국가는 인도와 파키스탄을 포함해 8 개국으로, 보유개수 순으로 보면 러시아 8500 기, 미국 7700 기, 프랑스 300기, 중국 250기, 영국 225기, 이스라엘 80기이다.

4) Mutual assured destruction (MAD) is a doctrine of military strategy and national security policy in which a full-scale use of high-yield weapons of mass destruction by two or more opposing sides would cause the complete annihilation of both the attacker and the defender. 
돌하고 있다는 점이다. ${ }^{6}$ ) 중국의 대외 $\mathrm{FDI}$ 의 4 분의 3 이 자원이 풍부한 아프리카 5 개국(수단, 알 제리아, 잠비아, 남아공 그리고 나이지리아)에 집중되고 있다.7) 특히, 나이지리아 원유에 대한 중 국과 서구진영의 맞대결은 앞으로 갈등의 불씨를 안고 있다.

제 I 장

중국은 아프리카를 중동 오일 공급원을 대신하는 에너지와 광물질의 공급원으로만 생각하고 있 는 것이 아니다. 중국에게 아프리카는 커다란 무기 수출시장이다. 중국산 무기를 도입하는 아프리 카국가들은 무기체계를 중국에 의존하다 보면 외교관계도 덩달아 의존하게 되는 것이다. 아프리 카 무기 수입의 $60 \%$ 는 유럽국가가 차지하고 있지만, 소형 무기 시장은 중국이 독점하다시피 하 고 있다. 게다가 스웨덴 국방 연구소(FOI) 보고서에 따르면 중국은 케냐, 이집트, 보츠와나, 모로 코 같은 국가를 $\mathrm{K}-8$ 이나 $\mathrm{JF}-17$ 같은 경전투기 잠재 시장으로 여기고 있다.

무기 판매와 석유 개발 대행으로 중국은 아프리카 국가들과 종속관계를 조직적으로 진행시켜 왔고, 그 결실이 바로 2006년 11월 중국 아프리카 협력 포름의 개최이다. 북경에서 개최된 제 1 회 중국-아프리카 협력 포럼(Forum on China-Africa Cooperation, FOCAC)에 48개 아프리 카 국가의 정상들이 참석했다.

중국은 에너지와 철강 수요가 국내생산으로 충족이 안되는 상황에 이르렀기 때문에 공격적 해 외 기업인수와 합작을 통해서 물량확보에 나섰다. 이를 위한 외교의 일환으로 2006년 11월 온가 보(溫家寶: 웬자바오) 총리는 7개 아프리카국가(콩고, 이집트, 가나, 앙골라, 남아공, 탄자니아, 우간다)를 순방했고, 2007년 초 중국 외무장관 이조성(李肇星: 리쟈오싱)은 보츠와나, 에리트리 아, 중앙아프리카 공화국, 차드, 기니아 대통령을 방문했다. 중국은 경제사정이 어려운 아프리카 에 부채 탕감, 수입관세 인하, 인적 교류와 교육 제공 등 패키지 협력 방안으로 접근하고 있다.

2009년 11월 이집트에서 개최된 제 4회 중국-아프리카 협력 포럼 (FOCAC)에 온가보 총리가 직접 참석해서 8개 항목의 협력증진 방안을 제시했다. 구체적인 분야는 기후변화, 과학 기술 협 력, 농업 분야 협력, 의료지원, 교육 및 인적자원 개발, 문화 교류가 거론되었다. 그 중 100 억 달 러 규모의 부채 탕감 및 재정 지원이 중국의 아프리카 공략의 핵심 내용이었다. 8) 2006년 이후 중국의 아프리카 경영은 가속도를 붙이고 있다. 그 예로 왕이 중국 외무장관은 2015년 아프리카

5) Jason Simpkins. "China Blazing Its Own Trail in Africa". Money Morning. September 30, 2009, available at http://moneymorning.com/2009/09/30/china-africa/ (접속일: 2016년 3월)

6) Lyman, Princeton. "China's Rising Role in Africa". Council on Foreign Relations. July 21, 2005, available at http://www.cfr.org/publication/8436/chinas_rising_role_in_africa.html (접속일: 2016년 3월)

7) Hellström, Jerker. 2009. "China's Emerging Role in Africa". Ursvik: Swedish Defence Research Agency(FOI). p.9, available at http://www.foi.se/upload/projects/Africa/China\%27s\%20Emerging\%20Role\%20in\%20Africa\%20-\%20a\%20 Strategic\%200verview.pdf (접속일: 2016년 3월)

8) http://www.chinese-embassy.org.za/eng/zt/FOCAC4/t625494.htm (접속일: 2016년 3월)

\section{제 II 장}


5개국을 방문했고, 2016년 올해만도 4개국 방문을 예정하고 있다. ${ }^{9)}$

중국 국영 기업인 $\mathrm{CNOOC}$ 는 나이지리아 원유 보유량의 6 분의 1 을 차지하는 분량인 60 억 배럴 의 원유를 구매할 계획이다. 금액으로 300 억 달러에서 500 억 달러에 이르는 막대한 규모이다. 이 계약은 나이지리아의 23 군데 원유 시추 공사를 진행 중인 세계 최대의 원유회사 엑손 모빌 (Exxon Mobil), 로얄 더치 셀(Royal Dutch Shell), 세브론(Chevron Corp), 토탈(Total)과 이 해가 상충된다. ${ }^{10)}$

중국이 아프리카에 관심을 갖는 이유는 오일만이 아니다. 중국은 철강석, 니켈, 동, 코발트, 보 크사이트, 은, 금 등 다른 천연 자원도 사들이고 있다. 2009년 중국은 아프리카의 최대 무역국으 로 1 천 70 억 달러의 교역량을 기록하며 미국을 앞질렀다. 중국이 투자하고 있는 아프리카 국가 수는 49 개 국에 이른다. 중국은 아프리카와 유대를 공고히 하기 위한 방법으로 많은 국제회의를 주최하고 있다. 대표적인 모임으로 터치로드 중국-아프리카 투자 포럼(Touchroad China-Africa Investment Forum)과 중국-아프리카 협력 포럼 (FOCAC)이 있다.

이런 가운데 몇 몇 서방 정부기관들은 중국이 아프리카 지인들은 안중에도 없이 아프리카의 자 원을 마구잡이로 점유하고 있다는 우려하는 목소리를 내고 있다. 특히, 중국이 국제사법재판소에 서 전범으로 고소한 수단의 오마르 바시르 대통령을 비롯해 미국과 유럽에서 기피하는 지도자인 짐바브웨 무가베 대통령과도 긴밀한 관계를 유지하고 있는 것을 못마땅해하고 있다.

미국의 헤리티지 재단 보고서에 따르면 중국이 수단과 짐바브웨의 독재 권력을 지원하는 것은 그들의 잘못된 정책을 합법화하는 역할을 하고 있다고 비판했다. 중국은 수단과 짐바브웨에 재정 지원뿐만 아니라 군사 지원도 제공하고 있다. 미국 국방부에 따르면 수단은 2003년과 2007년 사 이에 중국으로부터 79 억 달러에 해당되는 무기를 수입했다고 밝혔다.

한편, 중국은 아프리카에 대한 중국의 투자덕분에 아프리카가 2005년에서 2010년 기간 5년간 $5 \%$ 의 경제성장을 이룰 수 있었다고 주장하는 반면, 서방 인권단체들은 중국의 아프리카 진출은 중국만을 위한 것이며, 현지의 부정 부패를 눈감아 주는 결과로 부패된 정권을 강화시키는 역할 을 했다고 주장한다. 머니 모닝의 피츠 제럴드 편집장은 중국 지도자들은 인권과 핵 문제 등은 전혀 개의치 않고 있다고 말하며, 그들에게 중요한 것은 다른 국가가 어떻게 여기든 중국에 오일 을 제공하는 것 뿐이라고 말했다.

2009년 9월 상해에서 열린 터치로드 중국-아프리카 투자 포럼에서, 이 포럼의 창설자인 하열

9) http://www.focac.org/eng/ (접속일: 2016년 3월)

10) Jason Simpkins. "China Blazing Its Own Trail in Africa". Money Morning. September 30, 2009, available at http://moneymorning.com/2009/09/30/china-africa/ (접속일: 2016년 3월) 
휘(何烈辉: 헤리에후이)는 아프리카를 개발되지 않은 가난과 질병 그리고 폭력의 땅으로 생각하는 것은 잘못된 선입견이라고 말하고, 아프리카의 모든 국가들이 가난한 것은 아니며, 몇몇 아프리카 는 일인당 국민소득에서 중국 보다 높다고 주장했다. ${ }^{11)}$ 터치로드 중국-아프리카 포럼은 2008년 에 18 개국이 참가해서 처음으로 개최된 바 있다.

중국은 아프리카의 유일한 G20 회원국인 남아공에 대한 외교에 박차를 가하고 있다. 2010년 8월 24일 북경에서 양국의 교류와 우호관계를 상징하는 정상회담이 호금도 주석과 제이콥 주마 대통령간에 열렸다. 이 자리에서 종합적 전략관계(comprehensive strategic partnership)로 양 국관계를 격상하는데 합의했다. ${ }^{12)}$ 중국과 남아공이 국교를 수립한 지 12 년 만에 보인 다각적 교 류의 산물이다.

이처럼 중국의 적극적인 아프리카 공략은 자원 확보 차원의 경제적 이유 이외에 국제 정치적 입지를 강화하기 위한 방편이라는 사실이다. 서구 제국주의 열강들의 식민지였던 아프리카에서 중국의 증대하는 위상을 통해서 신 양극 체제라는 국제 질서 속에 벌어지는 지각변동을 감지하게 된다.

\section{5. 발칸 반도: 역사적 갈등이 잠재된 지역}

코소보는 2008년 독립을 선언했고, UN 회원국 중 69 개국이 이를 인정했다. 하지만 러시아, 중국, 인도, 브라질뿐만 아니라 유럽연합 회원국인 스페인과 그리스도 코소보의 독립 인정을 거부 하고 있다. 이에 대해서 예레미치 세르비아 외무장관은 코소보 문제가 $\mathrm{UN}, \mathrm{EU}$ 그리고 나토를 갈라놓고 있다고 지적하며, 세계의 3 분의 2 가 코소보를 독립국가로 인정하지 않고 있음을 언급하 며 커다란 이견을 보이고 있음을 부각시켰다.

국제사법재판소는 2010년 7월 22일 세르비아로부터의 코소보의 2009년 독립 선언이 국제법을 위반한 것이 아니라고 발표했다. 하지만 세르비아는 2008년 코소보의 독립 선언 당시 결코 인정 할 수 없다고 천명한 바 있다. 유대인과 아랍인들이 예루살렘을 서로의 성지로 여기듯이, 세르비 아인들은 코소보를 건국의 정신적 태동지로 여기고 있다. 코소보는 1999년 나토가 이끈 폭격 이 래로 UN관할 하에 있어왔다.

세르비아의 예레비치 외무장관은 세르비아는 코소보의 독립을 지금도, 일년 뒤에도, 10 년 뒤에 도 결코 인정할 수 없으며, 독립을 강행할 시에는 좌시하지 않을 것이라고 못박았다. 세르비아 코

11) http://www.chinadaily.com.cn/china/2009-09/29/content_8748541.htm (접속일: 2016년 3월)

12) http://www.chinese-embassy.org.za/eng/zxxx/t736768.htm (접속일: 2016년 3월) 
스투니카 총리는 세르비아 영토 내에 괴뢰정부의 탄생을 간접적으로 승인하는 것 자체가 모욕적 인 일이라고 표현하며, “코소보는 오직 세르비아에 속하는 우리 영토이기에 결코 그 누구에게도 줄 수 없는 문제이다”라고 강조한 바 있다.

코소보 문제는 국제 무대의 주요 국가들을 둘로 갈라 놓고 있다. 러시아 푸틴 총리는 자신의 대통령 임기를 끝내는 마지막 기자회견에서 스페인과 프랑스 경계에 있는 바스크 지역에 대한 독 립을 지지하지 않으면서, 코소보의 독립을 지지하는 유럽연합의 이중적 잣대를 비판하며, “유럽연 합이 코소보는 특별한 경우라고 주장하는 것은 날조이며 거짓이다”라고 강하게 반박했었다.

구 유고슬라비아 해체 이후, 지금의 유고슬라비아는 세르비아와 몬테네그로의 두 공화국으로 구성된 연방 국가이다. 코소보와 보이보디나는 세르비아 내의 주로서 1990년과 1989년까지 자치 지구였다. 코소보는 단독 정부를 구성했지만 세르비아와 유고슬라비아는 이를 인정하지 않고 있 고, 미국은 세르비아와 몬테네그로 연방을 인정하지 않고 있는 상태이다. 코소보의 인구는 알바니 아계가 $90 \%$ 를 차지하고, $10 \%$ 의 소수만이 세르비아계, 알바니아계는 코소보의 대다수를 차지하 지만 유고슬라비아 내에서는 소수민족이다.

조 바이든 미 부통령은 국제사법재판소가 코소보의 독립이 적법하다는 발표를 내기 전에 세르 비아 보리스 타디치 대통령에게 전화를 걸어 미국은 민주적이고 다민족의 코소보를 전적으로 지 원한다고 전달했고, 동시에 미국과 세르비아의 강한 유대를 확인했다고 알려졌다. 이는 물론 세르 비아를 설득하기 위한 방편이기도 하지만, 한편으로는 나토의 맹주입장에서 경고성 조치로도 해 석되고 있다.

세르비아 예제미치 외무장관은 반기문 UN사무총장을 만난 자리에서 코소보의 일방적인 분리 선언이 지역분쟁을 해결하는 방법이 되어서는 안된다는 것을 전달했다. 문제는 국제사법재판소의 발표는 법적으로 구속력을 띄지 않는다는 점이다. 즉, 코소보의 독립인정은 국제사법재판소의 의 견이지 판결이 아니라는 것이다. 하지만 국제사법재판소의 의견은 커다란 법적 무게를 싣고 있다 는 점에서 의미를 지닌다.

2008년 코소보의 일방적인 독립선언에 대해서 국제법을 위반한 것이 아니라는 국제사법재판소 의 의견은 러시아와 미국에게 더 이상 간섭하지 말라는 중요한 메시지를 전달하고 있다고 〈The Balkans: 1804 to 1999>의 저자 미샤 클레니는 뉴욕 타임즈 7월 27일자 기고를 통해서 밝혔다. 즉, 코소보 독립 문제는 유럽연합의 조력을 받아 세르비아와 코소보가 해결해야 한다는 것이다.

국제사법재판소의 의견은 국제법상 독립을 원하는 것은 문제가 없으나, 코소보가 완전 주권국 가가 아니기 때문에 국내법에 결부되지 않는다는 단서를 달고 있다. 코소보의 독립을 69 개국이 지지했지만, UN 회원국이 되기 위해서는 적어도 100 개국의 승인이 따라야 한다. 코소보의 일방 
적 독립 선언을 반대하는 국가들은 코소보 사례가 전 세계의 분리주의 운동을 더욱 부추길 것이 라는 우려를 이유로 들고 있다.

유럽연합 캐서린 애쉬톤 외무장관은 “유럽연합은 세르비아와 코소보간의 대화를 용이하게 할 준비가 되어있다”라고 즉각 성명을 발표하며, 그 대화가 유럽의 협력과 진보를 고무시킬 것이라고 덧붙였다. 애쉬톤 장관의 메시지는 코소보가 자국의 미래를 미국에 의존하지 말라는 메시지를 담 고 있다. 동시에 세르비아도 러시아에 코소보 독립 문제를 호소하지 말라는 뜻을 포함하고 있다.

유럽연합은 이미 발칸 반도 국가들도 회원국이 될 자격이 있다고 천명한 상태이기 때문에, 만 일 유럽의 앞마당과 같은 발칸문제를 해결하는 데 실패한다면, 유럽 역외의 문제에 영향력을 행 사하는데 위축될 것이 분명하다는 분석이다. 세르비아 정부는 유럽연합의 대부분의 회원국들이 코소보의 독립을 인정하고 있음에도 이를 영토 침범으로 보고 있다.

세르비아와 코소보가 유럽연합 회원국이 되기를 희망하는 상황에서, 서로 평화적 협력의 길을 택할 지 아니면 또 다른 무력 충돌로 유럽에서 아웃사이더가 될 지 귀추가 주목된다. 10년 전만 해도 유고 연방에서 독립한 크로아티아와 분리 독립을 반대한 세르비아는 서로 적대적인 관계였 지만 이제는 조직 범죄에 대한 공동 협력을 펴는 등 협조적인 관계로 발전한 것을 보면, 코소보 와 세르비아의 관계가 비관적이지만은 않다는 의견도 있다.

그러나 코소보 문제에서 분명히 드러나는 것은 세르비아 편을 드는 국가군이 중국과 러시아가 주축이 된 상하이협력기구( $\mathrm{SCO})$ 와 친 $\mathrm{SCO}$ 국가들이라는 사실이다. 즉, 중동 문제와 한반도 문제 에 이어 발칸 문제에서도 친(親)나토 진영과 $\mathrm{SCO}$ 가 대립각을 세우는 양상이다(조명진, 2010a).

게다가 발칸 반도는 지난 해부터 유럽 난민 유입 문제에 있어서 그리스를 거쳐서 독일 같은 전 쟁난민의 선호 정착 국가로 가기 위한 통로로 사용되어 왔다. 그러나 2016년 3월 들어서 마케도 니아와 슬로베니아가 난민 유입을 막기 위해서 국경을 차단하는 상황이 벌어지면서 다시 주목을 받고 있는 지역이다.

\section{6. 코카서스: 에너지 안보의 이해관계 충돌지역}

2008년 그루지야의 남오세티아 침공은 단순한 영토 분쟁이 아니었다. 러시아의 반격으로 그루 지야가 남오세티아를 점령하는 데에는 실패했지만, 분쟁의 불씨는 코카서스 일대에 걸쳐 남아 있 다. 미국 뉴욕 대학의 스테판 코헨 교수는 코카서스를 미국과 러시아의 대리 전쟁터라고 꼬집고 있다. 물론 이는 당장 그루지야를 가리켜서 한 말이지만, 이미 러시아군이 10 년 넘게 진주해 온 체첸공화국, 그루지야로부터 탈퇴한 남오세티아와 압카지아 그리고 인구세티아 자치공화국의 분 
쟁이 모두 해당된다.

코카서스는 동쪽으로 카스피 해, 서쪽으로는 흑해와 아조프 해를 경계로 한 지방이다. 코카서 스 산맥은 카스피해 남서 해안의 아프셰론 반도에서 흑해 북동 해안인 쿠반 강 어귀까지 약 $1,200 \mathrm{~km}$ 뻗어 있다. 유럽에서 가장 높은 산인 엘브루스 산 $(5,600 \mathrm{~m})$ 이 코카서스 산맥에 있다. 지정학적으로 코카서스 산맥은 터키의 이스탄불(과거 콘스탄티노플)이 유럽과 아시아를 나누는 것처 럼, 유럽과 아시아 두 대륙을 나누는 경계령이다. 남쪽은 터키 - 이란과 국경을 경계로 삼고 있다.

면적은 약 44만 $k m^{2}$ 로 한반도의 두 배가 넘는다. 남오세티아가 1999년 독립을 선언했지만, 그루 지야는 그것을 인정하지 않았다. 하지만 지난해 그루지야가 남오세티아를 침공한 것을 계기로 러 시아는 남오세티아와 압카지아를 동시에 독립국이라고 선언했다. 푸틴 총리는 8월 12 일 압카지아 를 방문해서 5 억 달러 상당의 안보 지원금을 약속했다. 이 자리에서 푸틴 총리는 그루지야의 사 카시빌리 대통령이 있는 한 코카서스에서 군사 충돌이 다시 일어날 가능성을 배제할 수 없다고 밝혔다.

문제는 사카시빌리 대통령이 2004년 대통령에 출마했을 때 압카지아와 남오세티아를 그루지야 영토로 복귀시키겠다고 공약한 것을 이행하려고 하기 때문에 2008년 남오세티아에 대한 침공을 시도했다는 점이다. 결과적으로 볼 때 러시아 메드베데프 대통령과 프랑스 사르코지 대통령 간의 휴전 협약으로 일단 잠잠해진 상태일 뿐이다.

러시아가 군사적으로 개입할 것을 알면서도 사카시빌리 대통령이 선거 공약을 과감하게 밀어붙 이는 배경에는 미국이 버티고 있다. 이미 부시 행정부는 체니 전 부통령을 통해 압카지아와 남오 세티아의 다수를 차지하고 있는 그루지야인들에 대한 보호 차원에서 그루지야를 두둔하는 입장을 밝혔고, 오바마 행정부 역시 같은 입장임을 바이든 부통령을 통해서 재확인한 바 있다.

그루지야 입장에서는 옛 소련이 강점하기 이전에 역사적으로 그루지야 영토였다는 명분을 갖고 있고, 러시아 입장에서는 소련 시절 스탈린이 현지인들을 타지로 강제 이주시키고 러시아인을 대 거 두 공화국에 이주시켰기 때문에 자국민 보호 차원이라는 명분을 띠고 있다. 이민족 간의 인위 적인 동반 거주지였다는 점에서, 또 러시아 정교와 이슬람교의 종교적 대립이라는 측면에서 북아 일랜드 문제와 흡사하다.

미국이 그루지야 편을 드는 두 가지 이유가 있다. 먼저 지정학적으로 터키와 국경을 맞대고 있는 그루지야를 나토 진영으로 영입하면 함께 러시아 남하 정책을 차단할 수 있다. 이미 아프가니스 탄에 테러와의 전쟁이라는 명분으로 나토군이 들어간 상태에서 그루지야까지 나토 영향력 아래에 두면 좀더 공고하게 러시아를 견제할 수 있게 된다. 둘째, 에너지 안보차원에서 유전이 있는 아제 르바이잔과 크라스노다르 - 스타브로폴 지역에서 출발하는 원유 파이프라인의 안전 확보 때문이다. 
코카서스의 지역 분쟁은 체첸과 인구세티아에서 나타난다. 체첸공화국은 반(反)러시아 깃발을 들고 지난 10 년간 독립 항쟁을 펼쳐왔으나 그 뜻을 이루지 못했다. 러시아 정부는 2009년 4월 체첸 반군에 대한 10 년간의 대 테러 작전을 종료한다고 선포했지만, 체첸 반군은 여전히 저항하 고 있는 상태이다. 게다가 체첸과 국경을 맞대고 있는, 친 러시아 정권이 권력을 잡은 인구세티아 자치공화국은 이슬람 무장 봉기 세력에 대해 공세를 강화하고 있는 상태이다.

냉전 시대 미국과 소련의 힘겨루기가 최고조에 달했던 1962년 쿠바 미사일 위기 때처럼 미국 과 러시아의 긴장감이 그루지야를 중심으로 한 코카서스에서 재현되는 양상이다. 쿠바 위기 때는 소련이 미국에 인접한 쿠바를 통해서 세력 확장을 시도한 반면, 이번에는 반대로 미국이 나토 확 대라는 명분으로 그루지야를 교두보로 삼고 러시아 남하 정책을 차단하려는 의도가 깔려 있다. 동시에 이란을 더욱 압박할 수 있는 전략적 포석이다. 하지만 나토 회원국 터키와 국경을 맞대고 있는 그루지야가 나토 회원국이 되는 것을 러시아로서는 좌시할 수 없는 상황이다.

안보와 경제적 측면이라는 복잡한 국제 관계 속에 코카서스의 주도권 경쟁은 '문명의 충돌' 요 소가 추가되면서 '신 냉전 시대'로의 진입을 예고하고 있다(조명진, 2009b).

\section{7. 한반도: 신 양극체제의 최전방}

한국은 실질적으로 파토(PATO)내에 속해 있기 때문에 6자 회담에서 상해협력기구(SCO)의 주 축국가인 러시아와 중국의 협조를 얻어내기가 점점 더 어려워지는 상황이다. 나토는 2004년 유럽 이외의 지역에서 교류와 협력을 강화할 국가를 이른바 '접촉국가(contact countries)'라고 분류하 고 일본, 호주, 뉴질랜드, 싱가포르와 함께 한국을 여기에 포함시켰다. 부시 행정부는 2006년부 터 구체적인 협력제안을 내놓았다. 미국은 그 해 나토 정상회의에서 나토와 한국, 일본, 호주, 스 웨덴, 핀란드 5 개국 간 협력관계 구축을 공식 제안했다. 이는 장기적인 관점에서 테러와의 전쟁 을 최우선 순위에 두고 있는 미국의 입장에서 한국 등 동맹국의 국제적 역할을 최대한으로 끌어 올리려는 미국의 세계전략의 일환이다.

스헤페르 전 나토 사무총장은 "전 지구적 위협이 상존하는 상황에서 나토는 어느 때보다 다른 나라의 도움에 의존하고 있다"며 “한국과 일본 등은 장래에 나토의 작전에 중요한 기여를 할 수 있을 것이다”라고 언급한 바 있다. 한국과 나토의 협력관계가 구체화될 경우 합동 군사훈련의 실 시를 전제로 한다는 점에서 주한미군의 한반도 이외 지역에서의 작전 등을 포함하는 주한미군의 전략적 유연성을 비롯하여, 한미동맹 관계의 미래 위상에도 긍정적인 효과를 기대할 수 있다. 게 다가 주한미군과의 연합훈련만이 아닌 나토의 다국적군과의 합동훈련은 한국군의 작전 능력을 향 
상시킨다는 점에서는 고무적인 일이다.

한국과 나토는 2008년 처음으로 정책협의회를 가졌고, 아프가니스탄 안정화, 핵 비확산, 테러 리즘 등에 대해 의견을 교환하고 군인 연수, 교육 등 인적 교류 강화에 대해서도 논의한 바 있다. 나토의 역할 확대에 따른 한국과의 안보협력은 ' 21 세기 신 양극 체제'에서 협력의 질을 높여준다. 하지만 동시에 중국을 위시한 $\mathrm{SCO}$ 국가와의 협력이 뒤로 밀려서는 안 된다.

친SCO에 속하는 대표적인 국가인 이란에 대한 $\mathrm{UN}$ 의 제재 결정으로 곤경에 처하게 된 것은 다름 아닌 한국이다. 한국의 제재 결정과 상관없이 금융거래가 사실상 전면 중단되면서 자동차, 철강, 정유 등 한국 실물경제가 타격을 피할 수 없게 됐다. 반면에 중국은 이란제재에 찬성하고도 이란과 경제협력을 확대해, 한국 기업의 경쟁력이 상대적인 약화되는 피해가 예상된다.

중동 산 원유를 많이 쓰는 한국 정유업체도 원유 공급에 비상이 걸렸다. 한국이 수입하는 원유 의 $10 \%$ 가 이란에서 나온다. 이처럼 이란의 경우를 보듯이, 한국은안보의안정장치를얻기위해서나 토와유대를공고히하고, 경제의 안정장치를 확보하기 위해서 $\mathrm{SCO}$ 를 동시에 상대해야 되는 다각적 이면서 균형 있는 경제외교안보 정책을 구사해야 한다.

2010년 6월29일에는 상해협력기구(SCO)의 양두마차인 러시아가 대규모 극동 군사 훈련이 시 작되었다. '동방 2010 으로 불린 이 훈련은 러시아가 극동 지역에서 실시한 것 중 전략 전쟁 훈련 이었다. 약 2 만 명의 병사와 30 척의 군함이 참가해, 7 월 8 일까지 계속되었다. 러시아의 3 대 함대 가 이번 훈련에 참가하기 위해 모두 동해상에 집결한 것으로 알려졌다.

한반도 정세가 긴장되어 있는 상황에서 실시된 러시아의 대규모 군사 훈련은 러시아의 각종 합 동 작전 능력 제고에 그 목표를 두고 있다고 발표되었지만, 동시에 동북아 지역에 대한 러시아의 영향력 확대 의도도 내포된 것으로 분석되고 있다.

중국 인민해방군이 미국의 공격을 가정한 시나리오에 따라 서해에서 야간 군사훈련을 실시한 것으로 전해졌다. ${ }^{13)}$ 홍콩의 사우스차이나모닝포스트는 8월 11 일 중국의 해방군보(解放軍報)를 인 용해, 인민해방군 북해함대 소속 전투기들이 최근 서해와 인접한 요동(遙東)·산동(山東)반도 상공 에서 미국의 가상 공격에 대비한 야간훈련을 실시했다고 보도했다. 신문은 또 “현대전에서 공중 공격은 항상 야간에 이뤼지는 점을 중시해 훈련이 새벽 1시 30 분부터 두 시간 동안 진행됐다”고 언급했다. 인민해방군 예비역 장성 출신의 군사평론가 예낙웅(倪樂雄-니러슝)은 "인민해방군이 야간 공격에 대처할 능력이 있음을 전 세계에 알리려 한 것으로 보인다”고 말했다.

13) 한국일보, 2010년 8월 11일 
한반도 주변 해역뿐 아니라 남중국해 역시 중 - 미 모두에게 중요한 전략적 요충지이다. 미국 싱크탱크인 '신 미국안전센터' 연구원 로버트 캐플런은 〈포린 어페어스〉 기고문에서 “중국 해군은 인도양으로 향하는 관문이자 세계의 화석연료 수송로인 남중국해로 더 많은 전력을 투입 중이다. 전략적 중요성을 놓고 볼 때 남중국해는 '제 2 의 걸프만'이다. 남중국해는 수십 년 동안 지정학의 핵심이 될 수 있다”라고 지적했다.

한반도 주변에서 실시되는 이러한 일련의 군사 훈련은 매우 이례적으로 시기가 집중되어 있고, 지점 역시 모두 한반도 주변 해역에서 진행되었다는 특징을 지니고 있다. 이러한 군사 훈련이 동 북아 혹은 인근 해역에서 때맞추어 잇달아 전개되고 있는 것은 한반도가 파토와 $\mathrm{SCO}$ 의 각축장이 되었다는 뜻이다.

\section{8. 북극: 새로운 자원 개발에 따른 이해 상충 지역}

북극 개발에 대한 관심은 기후 변화가 가져 온 새로운 영역이다. 왜냐하면 향후 30 년에서 40 년 뒤면 온난화의 영향으로 여름철에는 북극의 얼음이 완전히 녹아버릴 것으로 예상되기 때문이 다. 경제적 이득이 안보 이해와 맞물려 있다는 점에서 북극이 신 양극 체재의 새로운 지정학적 이해 충돌 지역이 되고 있다.

북극 개발의 첫 번째 이유는 천연 자원이다. 북극은 지구 표면의 $6 \%$ 를 차지하지만 채굴되지 않은 원유와 천연 가스의 $20 \%$ 가 매장된 지역으로, 그 가치자 10 조 5 천억 달러로 추정한다. ${ }^{14)}$ 그 리고 이미 바렌트 해 지역에서는 채굴이 진행 중이다.

북극에 관심을 갖는 또 다른 이유는 북극 항(Northern Sea Route 또는 Northeast Passage)15) 개발이다.

14) Ibid

15) The Canadians call the Northern Sea Route the North West Passage. It is interesting to see differences in naming the Arctic Shipping Route. In fact, the Canadian House of Commons passed in 2009 a bid to rename the North West Passage the Canadian North West Passage. The renaming of the passage can be attributed to the ongoing conflict between Canada and other countries, most notably the US, over the status of the passage. Canada considers it "internal waters", whereas the US and others consider it as an "international strait". The renaming can also be attributed to increased Canadian and international focus on the Arctic. From Statement on "Canada's Arctic Foreign Policy Pamphlet, August 2010", available at http://www.geopoliticsnorth.org/index.php?option=com_content\&view=article\&id=84:arctic-strategy-documents\&cati $\mathrm{d}=52 \&$ showall=\&limitstart=4 (접속일: 2016년 3월) 


\section{A Shortcut Across The Top of the World}

The Northeast Passage, across the Arctic Ocean, provides a shorter alternative for cargo vessels travelling between Europe and Asia than using the Suez Canal. It is shorter than the Panama Canal route for some voyages between the North American west coast and Europe.

LENGTH OF A VOYAGE TO ROTTERDAM FROM:

YOKOHAMA, JAPAN

12,894 miles via Suez Canal,

8,452 miles via Northeast Passage

SHANGHAI, CHINA

12,107 miles via Suez Canal,

9,297 miles via Northeast Passage

VANCOUVER, CANADA

10,262 miles via Panama Canal

8,038 miles via Northeast Passage

출처: http://www.star.nesdis.noaa.gov/star/documents/meetings/lce2013/dayOne/Sokolov_Russian.pdf

(접속일: 2016년3월)

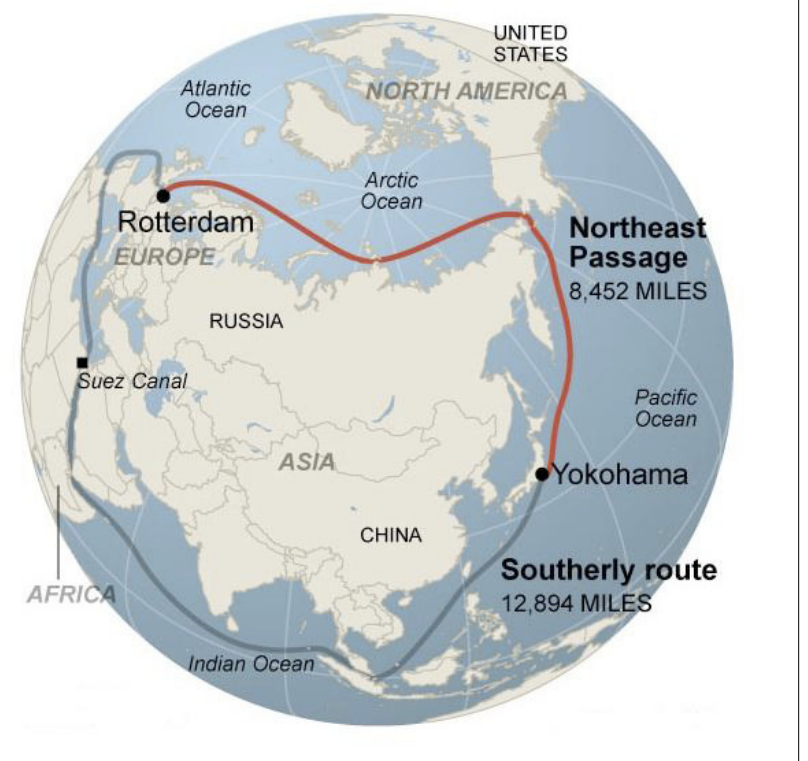

\section{df}

위 지도에서 보듯이 요코하마에서 로테르담까지 수에즈를 이용할 거리는 12,894 마일이지만, 북극 항로를 이용하면 8,452 마일로 단축된다. 상해의 경우도 마찬가지로 수에즈 운하를 통과할 때는 12,107 마일, 북극 항로는 9,297 마일이다. 벤쿠버의 경우에도 파나마 운하를 통과해서 로테 르담에 가는 거리는 10,622 마일이지만 북극 항로를 이용하면 8,038마일로 단축된다. 2010년에 여섯 척이 북극 항로를 통해서 태평양에서 대서양을 간 적이 있고, 2011년에는 68척이 이용하는 등 이미 북극 항로를 활용하고 있는 상태이다.

북극에 대한 직접 이해 당사국들의 국제 기구들 가운데 1996년에 설립된 북극이사회(Artic Council)가 북극과 맞닿은 국경을 둔 8개 회원국(미국, 캐나다, 러시아, 노르웨이, 덴마크, 스웨 덴, 핀란드, 아이슬란드)을 두고 있다. 그런데 북극 이사회에서는 자원 개발에 대한 이해 충돌이 나 안보 관련된 사안들을 다루고 있지는 않다. ${ }^{16)}$ 북극 이사회 회원국 가운데 $\mathrm{EU}$ 회원국은 덴마 크, 스웨덴, 핀란드이다. $\mathrm{EU}$ 북극정책의 3 대 목표17)는 다음과 같다.

16) http://europa.eu/rapid/press-release_MEMO-12-517_en.htm?locale=en (접속일: 2016년 3월)

17) Ibid, EU Arctic policy's 3 main objectives:

1. Protecting and preserving the Arctic in cooperation with the people who live there,

2. Promoting sustainable use of resources,

3. International cooperation 
1. 북극지역 거주자들과 협력을 통해 북극에 대한 보호와 보존

2. 지속 가능한 천연자원 활용

3. 국제협력

북극 이사회 회원국 가운데 미국, 캐나다, 노르웨이, 아이슬란드는 나토 회원국이다. 나토와 대 립 각을 구 바르샤바 조약기구 지역에서 세우고 있는 러시아의 군사 문제의 방향과 관련해서 러 시아 전략 2020(Russian National Security Strategy to 2020)에 이렇게 언급되어 있다.

The new strategy points at failure of the current global and regional security architecture, as it is disproportionately weighted in favour of NATO. It voices Russia's long-standing opposition to any future eastward enlargement of the Alliance and plans to move its military infrastructure to Russian borders, as well as attempts to give the organisation global functions. At the same time, it expresses Russia's readiness to negotiate and develop relations with NATO on the condition of equality and respect for Russia's interests. ${ }^{18)}$

전략에 언급되어 있듯이, 러시아 입장에서 북극의 에너지 자원 개발권을 차지하는 것은 불가피 하다. 2012년 이후로 러시아는 과거 냉전 시절 사용하던 군사적 공항을 다시 활용으로써 북극 지 역에 대한 군사력 증강에 박차를 가하고 있다. ${ }^{19)}$

구체적으로 2013년 초음속 요격기 Mig-31기 편대를 노바야 젬야(Novaya Zemlya) 반도에 배치했다. 이 요격기를 임무는 북극으로부터 적의 항공 공격으로부터 러시아를 방어하는 것이 다. 20) 2014년 10월 31일자 바렌트 옵져버에 따르면, 러시아 해군의 키로브 급 핵 순양함 어드미 럴 나키모프(Admiral Nakhimov)가 현대화 작업을 거쳐서 2018년에 북부 함대에 재배치될 전망 이다. 21) 2020년까지 러시아의 북극 지역에 대한 전략 개발은 2013년 2월 20일 푸틴 대통령에

18) The Russian government adopted a new Arctic strategy in September 2008. The document, entitled "The fundamentals of state policy of the Russian Federation in the Arctic in the period up to 2020 and beyond", from Zysk, Katarzyna. "Russian National Security Strategy to 2020". GeoPolitics in the High North. June 15, 2009, available at http://www.geopoliticsnorth.org/index.php?option=com_content\&view=article\&id=2: russia-norwayand-the-high-north-past-present-future\&catid=3\&ltemid=71\&showall=\&limitstart=3 (접속일: 2016년 3월)

19) Trude Pettersen. "Russia reopens Arctic airbases" The Barents Observer. May 31, 2012, available at http://barentsobserver.com/en/security/russia-reopens-arctic-airbases (접속일: 2016년 3월)

20) Trude Pettersen. "Russia sends Mig-31 interceptors to the Arctic". The Barents Observer. September 25, 2012, available at http://barentsobserver.com/en/security/russia-sends-mig-31-interceptors-arctic-25-09 (접속일: 2016년 3월)

21) Trude Pettersen. "Soviet nuclear battle cruiser to be re-launched". Barents Observer. October 31, 2014, available at http://barentsobserver.com/en/security/2014/10/soviet-nuclear-battle-cruiser-be-re-launched-31-10 (접속일: 
의해서 추인된 상태이다. ${ }^{22)}$

국제 해양법이 200해리로 영해 권리를 보장하고 있기에 북극 지역의 새로운 영해 문제가 불거 질 전망이다. 특히, 미국과 러시아는 베링해(Bering Sea)와 축치해(Chukchi Seas)를 두고 영해 분쟁을 벌이고 있어서, 잠재적인 안보 이해의 충돌이 예상된다. ${ }^{23)}$

\section{결론}

이번 기고 글에서 신 양극체제의 틀에서 국제 안보 중요성 면에서 비중을 차지하는 8개 지역을 조망함으로써 국제 안보 정세 변화의 추이들이 서로 상관관계가 있음을 보았다. 국제 정세는 국 제협력 뿐만 아니라 국제 경제에도 직접적인 영향을 준다. 그 한 예가 국제가 원유가의 변동이 국제 안보 정세와 민감하게 연관되어 있다는 사실이다.

둘로 나누인 이슬람 세계에서 중동의 안보 정세 변화는 과거의 양상과 다르게 전개되고 있다. 인더스 강의 수자원 개발을 둘러싼 인도와 파키스탄의 분쟁 조짐이 캐쉬미르에서 관찰되고, 발칸 반도에서 역사적 갈등이 친 $\mathrm{SCO}$ 의 세르비아와 여타 친 서방 국가 간에도 잠복해있다. 현재는 소 강 국면에 있는 코카서스 지역에서 에너지 안보의 이해관계 충돌은 언제든지 재현될 수 있다.

이번에 다룬 8 개 지역 중에 지정학적 이해충돌 지역인 아프가니스탄, 한반도, 북극 3 곳은 지리 적으로 파토와 친 $\mathrm{SCO}$ 진영이 맞닥트리고 있는 지역이라는 점에서 무력 충돌의 잠재성은 물론 무 력 분쟁의 스케일이 여타 지역보다 크다. 미군의 한반도 사드 배치 문제를 놓고 중국과 러시아가 반대하는 공조 입장을 보이고 있는 점은 지금의 국제 안보 정세가 신 양극 체제로 설명되는 좋은 예이다. 무엇보다도 한반도의 긴장 국면은 북한의 갑작스러운 붕괴를 상정할 경우, 북중러 연합군 과 한미일 연합군의 대치 가능성이 그 어느 때보다도 높다는 점은 국제 안보 정세에 불안한 요소 이다.

기후 변화의 해빙에 따른 자원 개발과 새로운 안보 이해충돌 지역으로 떠오르는 북극 지역까지 다루면서 얻게 된 결론은 국제 안보 정세는 이해관계의 조정과 충돌 과정을 거치면서 변화하고 있는 사안이라는 점이다. 이처럼 국제 개발 협력 방향을 설정하는데 있어서 국제 정세에 대한 지 속적인 정보 분석을 토대로 한 접근할 필요성이 제기된다.

2016년 3월)

22) http://www.star.nesdis.noaa.gov/star/documents/meetings/lce2013/dayOne/Sokolov_Russian.pdf (접속일: 2016년 3월)

23) http://news.yahoo.com/russian-ships-old-arctic-nato-set-alarms-bells-050008186.html (접속일: 2016년 3월) 


\section{〈참고문헌〉}

조명진. 2008. 『세계 부와 경제를 지배하는 3 개의 축』. 서울: 새로운 제안 2009a. "21세기 나토의 역할과 위상”. 서울: 미래전략연구원 2009b. “미·러 맞붙은 “신 냉전'의 땅 코카서스”. 서울: 시사저널 2010a. “분열의 상처 아물지 않는 발칸". 서울: 시사저널 2010b. 『우리만 모르는 5년 후 한국 경제』. 서울: 한국경제신문사

GeoPolitics in the High North. "Canada's Arctic Foreign Policy Pamphlet, August 2010" . GeoPolitics in the High North, available at http://www.geopoliticsnorth. org/index.php?option=com_content\&view=article\&id=84:arctic-strategy - docum ents\&catid $=52 \&$ showall=\&limitstart=4 (접속일: 2016년 3월)

Hellström, Jerker. 2009. "China's Emerging Role in Africa". Ursvik: Swedish Defence Research Agency(FOI), available at http://www.foi.se/upload/projects/ Africa/China\%27s\%20Emerging\%20Role\%20in\%20Africa\%20-\%20a\%20Strategic\% 200verview.pdf (접속일: 2016년 3월)

Jason Simpkins. "China Blazing Its Own Trail in Africa". Money Morning. September 30, 2009, available at http://moneymorning.com/2009/09/30/china-africa/ (접속일: 2016년 3월)

Lyman, Princeton. "China's Rising Role in Africa". Council on Foreign Relations. July 21, 2005, available at http://www.cfr.org/publication/8436/ chinas_rising_role_in_africa.html (접속일: 2016년 3월)

Trude Pettersen. "Russia reopens Arctic airbases". The Barents Observer. May 31, 2012, available at http://barentsobserver.com/en/security/russia-reopensarctic-airbases (접속일: 2016년 3월)

. "Russia sends Mig-31 interceptors to the Arctic". The Barents Observer. September 25, 2012, available at http://barentsobserver.com/en/security/russiasends-mig-31-interceptors-arctic-25-09 (접속일: 2016년 3월)

"Soviet nuclear battle cruiser to be re-launched". Barents Observer. October 31, 2014, available at http://barentsobserver.com/en/security/2014/10/ soviet-nuclear-battle-cruiser-be-re-launched-31-10 (접속일: 2016년 3월)

Zysk, Katarzyna. "Russian National Security Strategy to 2020". GeoPolitics in the High North. June 15, 2009, available at http://www.geopoliticsnorth.org/ index.php?option=com_content\&view $=$ article\&id $=2$ : $r u s s i a ~-$ norway - and - the - hi

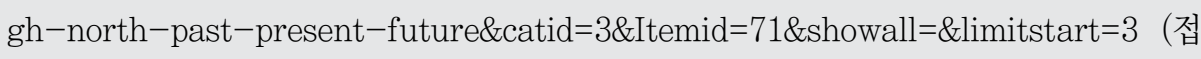
속일: 2016년 3월) 